\title{
УДК 528.46:711.14
}

Ю. ДЕНИС, Х. БУРШТИНСЬКА, О. ПАШТЕТНИК

Кафедра фотограмметрії та геоінформатики, Національний університет “Львівська політехніка”, вул. С. Бандери, 12, Львів, Україна, 79013, e-mail: yuliya.denys@gmail.com

\section{МОНТТОРИНГ ЗАСИХАННЯ ХВОЙНИХ ЛІСІВ ЗА РІЗНОЧАСОВИМИ КОСМІЧНИМИ ЗНІМКАМИ (НА ПРИКЛАДІ ТУХЛЯНСЬКОГО ЛІСНИЦТВА)}

Мета роботи полягає у виявленні ділянок із засиханням хвойних лісів на підставі спектральних яскравостей зображень із використанням польових досліджень та у створенні навчальних вибірок для здійснення контрольованої класифікації для обчислення площ ділянок із засиханням хвойних дерев. Методика. Для моніторингу стану лісів Тухлянського лісництва використано комплексну методику, основану на використанні різночасових космічних знімків середнього розрізнення 3 подальшим їх опрацюванням за допомогою геоінформаційних систем. На ділянці досліджень у 2007 р. за матеріалами аерознімання електронно-оптичною камерою створено ортофотоплани із позначеними ділянками, на яких виявлено засихання хвойних дерев. Польові дослідження полягали в ідентифікації вибраних на ортофотоплані п'яти ділянок і виявленні змін щодо засихання хвойних лісів за десятиліття. Дослідження стосувались вибору тестових зразків для подальшого опрацювання космічних знімків, отриманих із супутників Landsat 5 (2007 р.) та Sentinel 2 (2017 і 2018 pp.), методом контрольованої класифікації. Контрольована класифікації дає можливість визначати масштаби засихання лісів за останні 11 років, зміни ландшафту та визначати площі засихання лісів. Результати. Дослідження проведено на території Тухлянського лісництва Сколівського району Львівської області. Для польових досліджень вибрано п'ять ділянок із відомими координатами, на яких виявлено засихання. 3 метою збирання завіркової інформації на ці ділянки організовано дві експедиції. На підставі завіркової інформації створено навчальні вибірки. Для оцінювання навчальних вибірок використано гістограми та діаграми розсіювання. Контрольовану класифікацію здійснено за методом максимальної вірогідності на територію лісництва 3 подальшим постопрацюванням. Ідентифіковано нові ділянки із засиханням хвойних дерев та визначено площі засихання. Наукова новизна та практична значущість. Запропонована методика дає змогу достовірно та 3 достатньою точністю вести моніторинг лісових масивів, а також контролювати поширення засихання у лісах і відповідно, приймати вчасні управлінські рішення щодо зменшення осередків поширення шкідників у хвойних лісах. Опрацьовану методику та отримані результати досліджень доцільно використовувати у лісовому господарстві для здійснення оперативного лісового моніторингу.

Ключові слова: моніторинг лісів; засихання хвойних лісів; космічні знімки; класифікація; навчальні вибірки.

\section{Вступ}

Моніторинг лісів - це система спостережень, оцінювання i прогнозування стану i динаміки лісового фонду для державного управління в галузі використання, охорони, захисту лісового фонду, відтворення лісів і покращення їхіх екологічних функцій.

Моніторинг лісів передбачений низкою законів та рішень Уряду України, зокрема Лісовим кодексом України (2006), Постановою Кабінету Міністрів України № 391 від 30 березня 1998 р. про затвердження "Положення про державну систему моніторингу довкілля", Постановою Кабінету Міністрів України № 581 від 29 квітня 2002 р. про затвердження державної програми “Ліси України на 2002-2015 роки”.

Сучасна система управління лісами в Україні створена ще декілька десятиліть тому і досі не зазнала суттєвих змін. Вона характеризується вузькою спрямованістю на розв'язання лісогосподарських завдань. Зокрема, бракує інформації про об'єкти природно-заповідного фонду, рекреаційні ресурси галузі, відомостей щодо лісового моніторингу. Така обмеженість поширюється і на інформаційні системи, які використовують чи розробляють у цій галузі [Зацерковний, Оберемок, Ягорлицька, 2017].

Доцільність використання матеріалів дистанційного зондування Землі для моніторингу стану лісів визначається їхніми перевагами над традиційними методами, зокрема високою інформативністю даних дистанційного зондування, їх об' єктивністю, регулярністю отримання та широкими можливостями опрацювання цих матеріалів для значних територій [Бурштинська, Поліщук, Ковальчук, 2013]. Дані супутникових спостережень, зокрема, зображення середнього просторового розрізнення із супутників 
cepiï Landsat та Sentinel $є$ ефективним інструментом моніторингу стану лісів [Grinandabc, Rakotomalalacd, Gonde, Vaudryc, Bernouxg, Vieilledentef, 2013; Hais, Wild, Berec, Brůna, Kennedy, Braaten, Brož, 2016)]. Накопичені до сьогодні довгострокові архіви даних відкритого доступу уможливлюють одержання інформації про ліси для всієї території України.

Технології дистанційного зондування дають змогу створити системи моніторингу лісів, зокрема визначення структури насаджень, виявлення великомасштабних змін у лісах унаслідок впливу пожеж, вирубок й інших чинників, оцінку індикаторів стану лісової рослинності [Зацерковний, 2017; Bochenek, Ziolkowski, Bartold, Orlowska, Ochtyra, 2017].

У [Viewegh, Kusbach, Mikeska, 2003] вказано, що під час моніторингу лісів доцільно враховувати екологічні чинники довкілля. Запропоновано користуватись екологічною сіткою.

Глобальні зміни клімату, підвищення температури та зменшення кількості опадів сприяють розвитку шкідників, які найпоширеніші в хвойних лісах. Як зазначено на офіційному сайті ДП “Славське лісове господарство”, загальна площа осередків шкідників i хвороб лісу на початок 2012 р. досягала 6171 га, зокрема пошкоджено стовбуровими шкідниками 524 га лісу та хворобами 5647 га. Лісники зазначають, що переважна більшість хвойних дерев, які засихають, росте не у сприятливих для них умовах, тобто в ялицевих та букових типах лісу, що робить ці лісостани потенційно вразливими до дії кліматичних чинників (це різкі коливання температури взимку, відсутність опадів та висока температура повітря в період вегетації) та біотичних (кореневі гнилі, комахиксилофаги, фітонематоди). Все це призводить до фізіологічного ослаблення дерев та активізації розвитку патогенних організмів (фітопатогенних грибів, комах-фітофагів) [ДП “Славське лісове господарство”, 2013].

Традиційний підхід до еколого-економічної оцінки уражень лісу, який застосовується сьогодні на експертному рівні, коли вже відомі розміри та розташування проблемних лісових масивів, не орієнтований на своєчасне оперативне визначення вогнищ уражень, їхніх масштабів і оцінювання можливих наслідків. Тому такий підхід не дає змоги приймати своєчасні рішення в управлінні діяльністю лісоохоронних служб. Доцільність залучення технологій геоінформаційних систем та матеріалів дистанційного зондування для виявлення уражених ділянок лісу пояснюється високим ступенем оперативності моніторингу на великій площі охоплення, що найважливіше для територій лісових регіонів [Зацерковний, Тішаєв, Шишенко, 2016; Котляревська, 2010].

\section{Мета}

Мета дослідження полягає у виявленні ділянок із засиханням хвойних лісів за матеріалами польових досліджень для створення навчальних вибірок та здійсненні контрольованої класифікації для обчислення площ та ідентифікації нових ділянок із засиханням хвойних дерев.

\section{Методика}

Завдання дослідження - опрацювання космічних знімків, отриманих із супутників Landsat 5 (2007 р.) та Sentinel 2 (2017 i 2018 роки), на територію Тухлянського лісництва 3 метою визначення зміни площ засихання хвойних лісів.

Класифікація зображень - це процес групування пікселів зображення у певні класи, що представлятимуть той самий об'єкт на місцевості. Розрізняють два типи класифікації: контрольовану та неконтрольовану.

На підставі опрацьованої літератури [Лялько, Попов, 2006; Миклуш, Гаврилюк, Часковський, 2012] та попередніх досліджень [Burshtynska, Polishchuk, Madyar, 2014] для проведення контрольованої класифікації вибрано метод максимальної вірогідності. Метод максимальної вірогідності грунтується загалом на ймовірності належності певного піксела до визначеного класу об'єкта. Умовою розв'язання є припущення, що всі вірогідності однакові для всіх класів і мають нормальний закон розподілу даних.

Класифікацію за методом максимальної вірогідності виконують за формулою (1):

$$
\begin{aligned}
& D=\ln \left(a_{m}\right)-\left[0.5 \ln \left(\left|\operatorname{COV}_{m}\right|\right)\right]- \\
& -\left[0.5\left(X-M_{m}\right)^{T}\left(\operatorname{COV}_{m}^{-1}\right)\left(X-M_{m}\right)\right]
\end{aligned}
$$

де $D$ - вагова відстань (вірогідність); $a_{m}$ - відсоток вірогідності належності класифікованого піксела до класу m (дорівнює 1.0 або вводиться на основі апріорних даних); $C O V_{m}$ - коваріаційна матриця пікселів у сигнатурах класу $\mathrm{m}$; $C O V_{m}{ }^{-1}$ - обернена до $C O V_{m}$ матриця; $T$ - знак транспонування матриці.

Якщо для піксела обчислена вагова відстань $\mathrm{D} \epsilon$ мінімальною, то він належить до класу $\mathrm{m}$ [Шпак, 2012].

Важливим етапом контрольованої класифікації $\epsilon$ створення навчальних вибірок. Навчальні вибірки - це ділянки зображення, які створюють для того, щоб представляти різні класи. Для дослідження використано полігональний спосіб додавання вибірок. Вибірки створено на основі польових досліджень.

На рис. 1 подано структурну схему дослідження. 


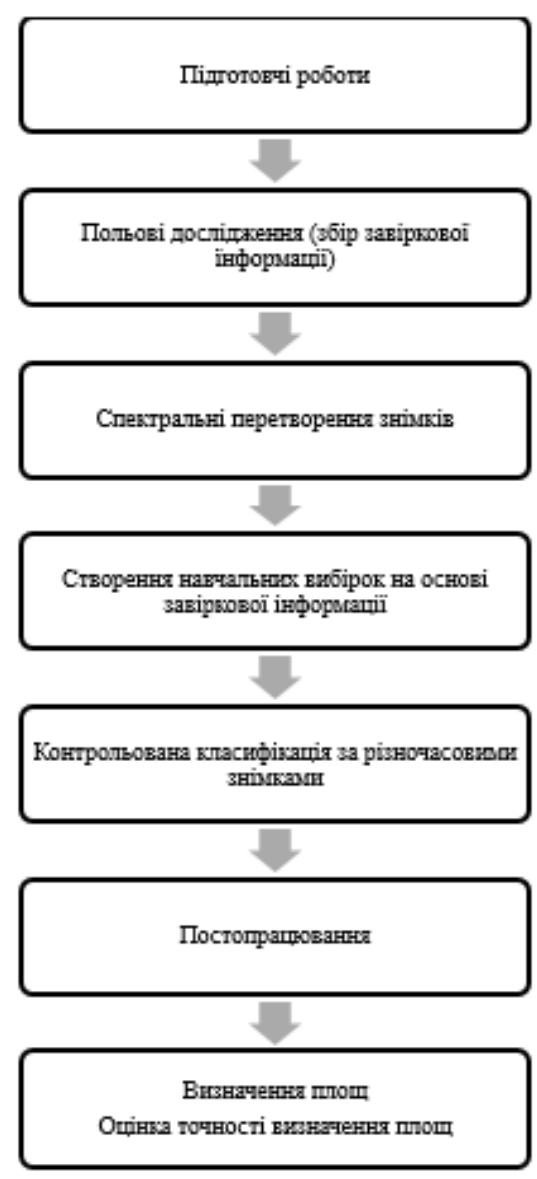

Рис. 1. Структурна схема дослідження

\section{Результати}

Дослідження проведено на території Тухлянського лісництва Сколівського району Львівської області. Загальна площа лісництва становить 4888 га. Тухлянське лісництво входить до складу ДП “Славське лісове господарство” і розташоване у північно-східній частині на території Сколівського району. На рис. 2 показано межі Тухлянського лісництва та ділянки, на яких виявлено засихання хвойних лісів.

Територія лісництва належить до ЦентральноЄвропейської провінції Європейської зони, зони широколистяних лісів Східно-Карпатської гірської підпровінції, смереково-ялицево-букових та смерекових лісів фізико-географічного району Сколівських Бескид. За характером рельєфу ліси на цій території належать до гірських [ДП “Славське лісове господарство”, 2013].

Для збирання завіркової інформації вибрано п’ять ділянок із відомими координатами, на яких виявлено засихання хвойних лісів та організовано дві експедиції для уточнення інформації: восени 2017 р. та весною 2018 р. [Денис, Паштетник, Поліщук, 2017].

Для кожної з п'яти обстежених ділянок записано такі дані:

- $\quad$ загальна характеристика полігона;

- $\quad$ види дерев;
- $\quad$ частота виду, \%;

- $\quad$ середня висота дерева, м;

- $\quad$ середня товщина стовбура, м;

- $\quad$ середня відстань між деревами, м;

- ступінь засихання, \%.

Загальна територія обстежених ділянок - близько 50 га. В результаті обстеження на ділянках виявлено різні ступені засихання хвойних насаджень, від $10 \%$ до $50 \%$ (рис. 3). Виявлено, що частина засохлих дерев, зокрема на схилах, повалені буревіями, що унеможливлює ї ідентифікацію на знімках середнього розрізнення (рис. 4).

Для проведення моніторингу використано космічні знімки літнього періоду (серпень) із знімальних систем Landsat 5 (2007 рік) та Sentinel 2 (2017 і 2018 роки), що надає Геологічна служба США (USGS).

На основі польових досліджень створено навчальні вибірки, які характеризують такі класи: ділянки із засиханням хвойних дерев, лісові масиви, галявини та стежки. До класу “галявини” входять i вирубки. Для оцінювання навчальних вибірок використано гістограми та діаграми розсіювання. Встановлено, що класи не перетинаються у просторі ознак. На рис. 5, 6 подано гістограми та діаграми розсіювання для навчальних вибірок на знімку 2018 р.

Для процесу згладжування на отримані класифіковані зображення накладено Majority Filter. Результати класифікації на знімках за 2007, 2017 та 2018 роки наведено на рис. 7, 8 та 9 відповідно.

В результаті отримано площі кожного класу за 2007, 2017 та 2018 роки (табл. 1).

Таблиця 1

Визначені площі класів

\begin{tabular}{|c|c|c|c|}
\hline \multirow{2}{*}{ Класи } & \multicolumn{3}{|c|}{ Площа, га } \\
\cline { 2 - 4 } & 2007 & 2017 & 2018 \\
\hline засихання & 283,7 & 507,21 & 486,9 \\
\hline ліс & 4252,0 & 3907,1 & 3859,7 \\
\hline стежки & - & 186,2 & 201,8 \\
\hline галявини & 326,0 & 262,6 & 314,8 \\
\hline
\end{tabular}

У табл. 2, 3 наведено різниці площ класів за 20072017 pр. та 2017-2018 рр. відповідно.

Таблиия 2

Різниця площ класів за 2007-2017 рр.

\begin{tabular}{|l|r|r|r|}
\hline \multirow{2}{*}{\multicolumn{1}{|c|}{ Класи }} & \multicolumn{3}{|c|}{ Площа, га } \\
\cline { 2 - 4 } & 2007 & 2017 & \multicolumn{1}{l|}{ різниця } \\
\hline засихання & 283,7 & 507,2 & 223,5 \\
\hline ліс & 4252,0 & 3907,1 & $-344,9$ \\
\hline галявини & 326,0 & 448,9 & 122,9 \\
\hline
\end{tabular}




\section{Таблиия 3}

Різниця площ класів за 2017-2018 рр.

\begin{tabular}{|c|c|c|c|}
\hline \multirow{2}{*}{ Класи } & \multicolumn{3}{|c|}{ Площа, га } \\
\cline { 2 - 4 } & 2017 & 2018 & різниця \\
\hline засихання & 507,2 & 486,9 & $-20,3$ \\
\hline ліс & 3907,1 & 3859,7 & $-47,4$ \\
\hline стежки & 186,2 & 201,8 & 15,6 \\
\hline галявини & 262,63 & 314,8 & 52,2 \\
\hline
\end{tabular}

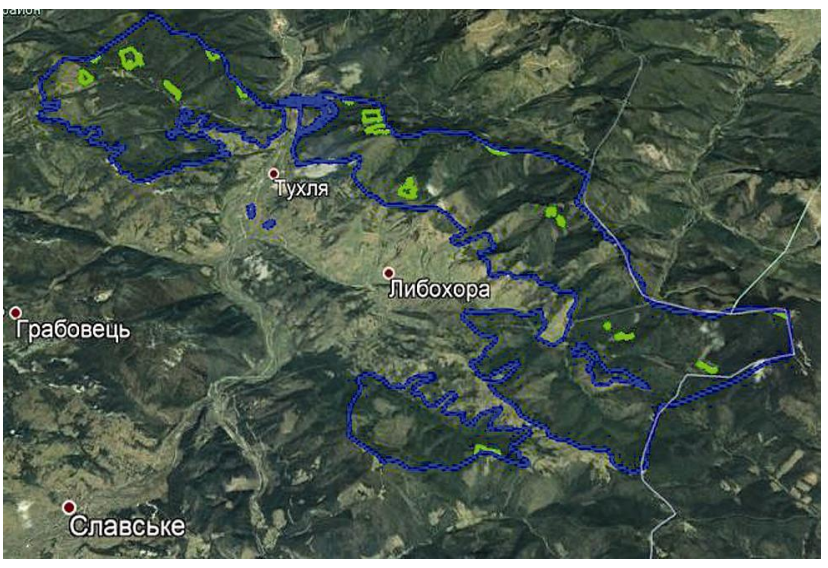

Рис. 2. Межі Тухлянського лісництва з позначеними ділянками засихання хвойних дерев
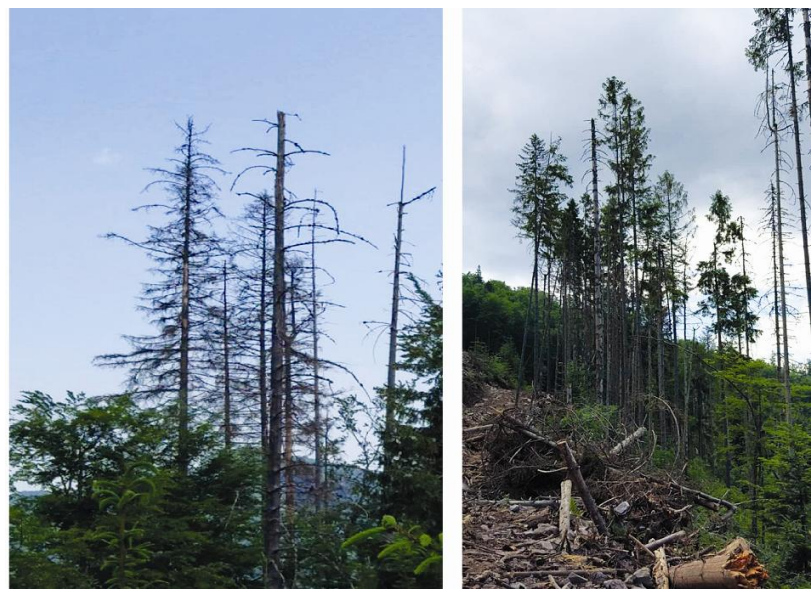

Рис. 3. Ділянки із засиханням хвойних дерев

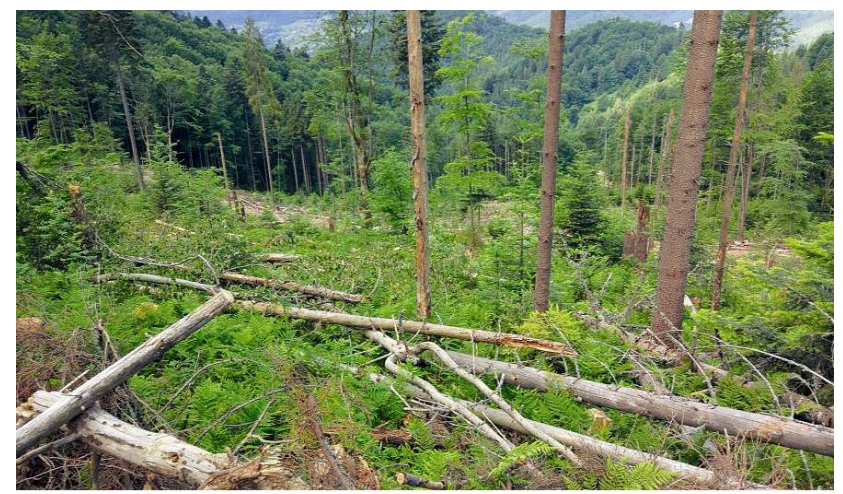

Рис. 4. Ділянки із поваленими засохлими деревами
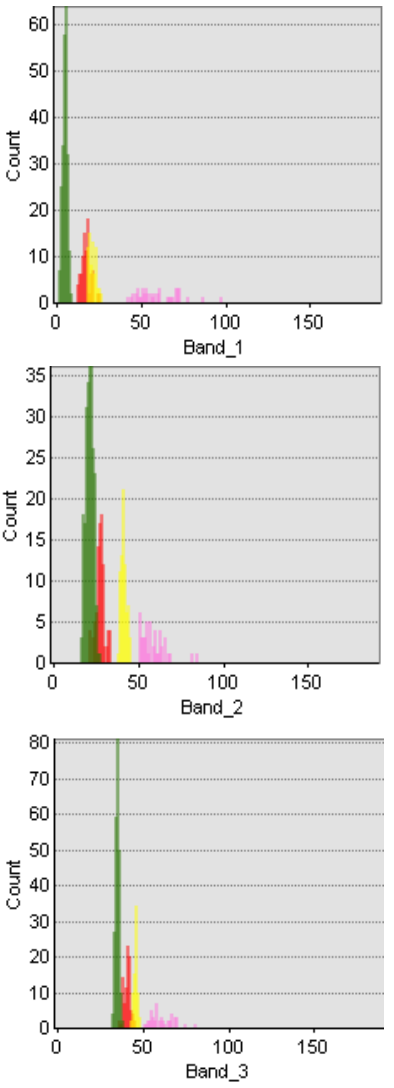

Рис. 5. Гістограми для створених навчальних вибірок
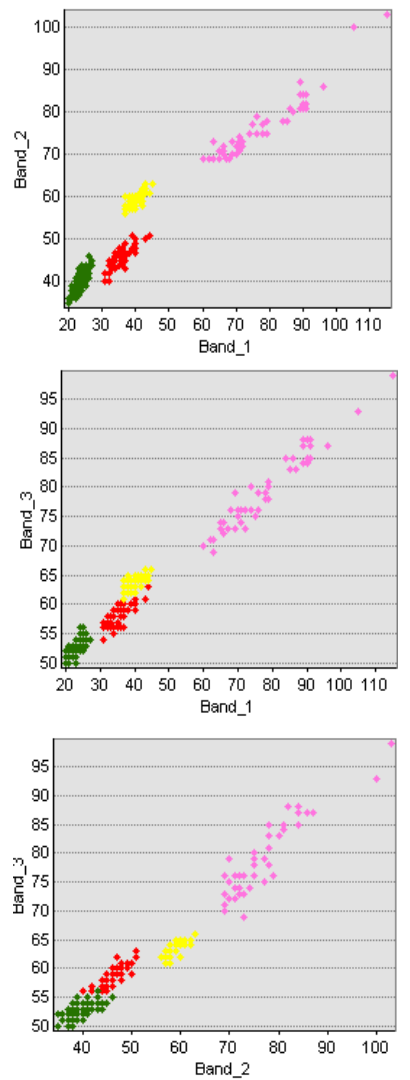

Рис. 6. Діаграми розсіювання для створених навчальних вибірок 


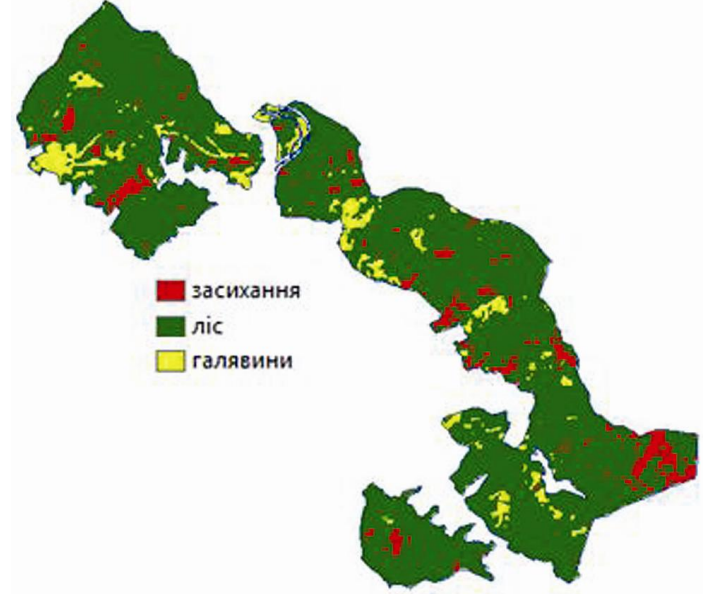

Рис. 7. Результат класифікаиії за 2007 р.

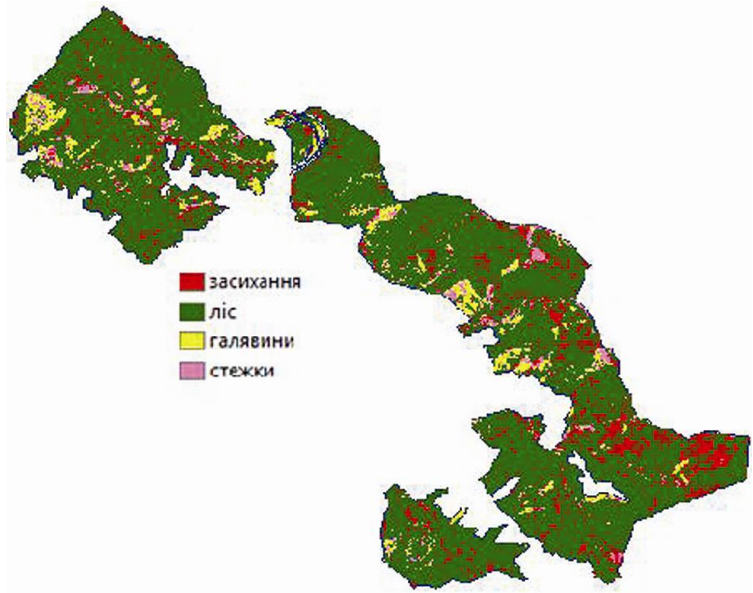

Рис. 8. Результат класифікаиї̈ за 2017 р.

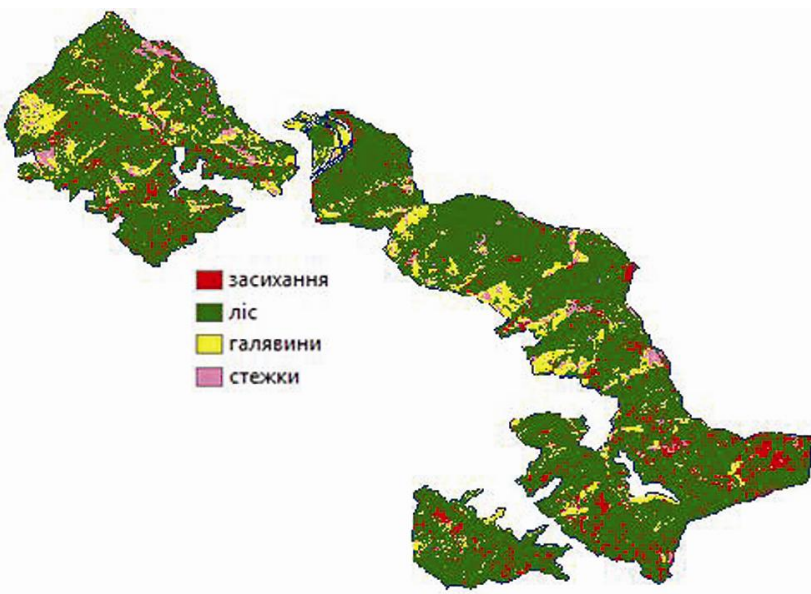

Рис. 9. Результат класифікачиї за 2018 p.
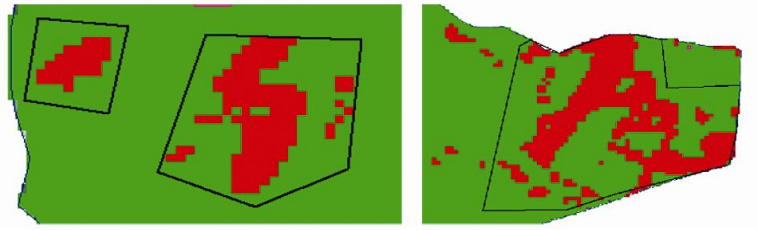

Рис. 10. Додатково ідентифіковані ділянки із засиханням хвойних дерев (на 2007 р.)

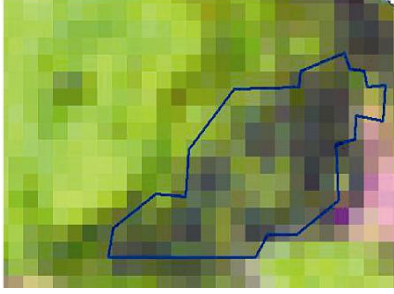

$a$

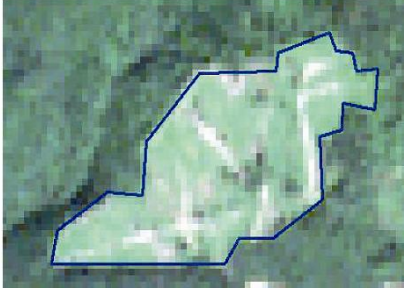

$\sigma$
Рис. 11. Приклад вирубування лісу: $a-2007 p ., \sigma-2017 p$.

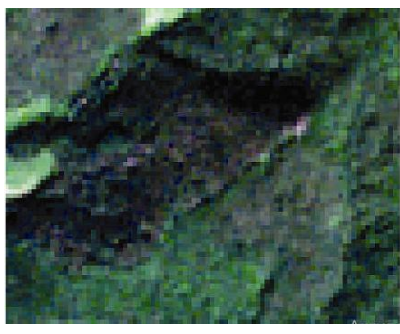

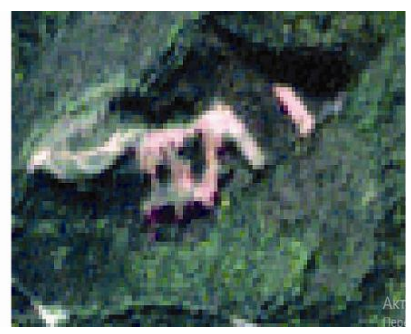

$\sigma$
Рис. 12. Приклад вирубування пошкодженого хвойного лісу: $a-2017$ p.; $б-2018 p$.

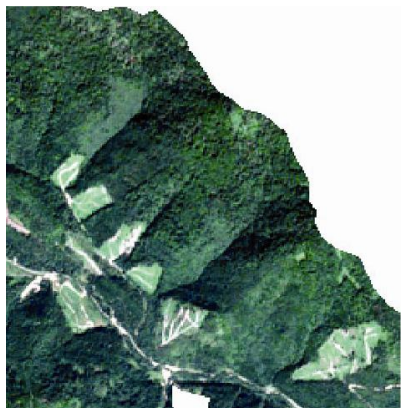

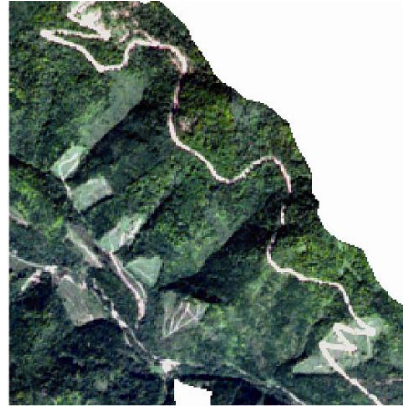

Рис. 13. Приклад прокладення дороги до ділянок з сухостосм: $a-2017 p . ; \sigma-2018 p$.

Проаналізувавши результати, відзначимо пік найбільшого засихання у 2017 р. За 2007-2017 рр. лісництво втратило 344,9 га здорового лісу, висохло 223,5 га та вирубано 122,9 га. Порівнюючи 2017 р. 3 2018 р., також бачимо, що втрачено лісу на 47,4 га, засихання зменшилося на 20,3 га. Це пояснюється падінням засохлих дерев та їх вирубуванням, що спричинило збільшення площ класів галявин та стежок на 52,2 та 15,6 га відповідно.

За результатами класифікації за знімком 2007 р. виявлено додаткові ділянки із засиханням дерев (рис. 10), не позначені на ортофотоплані лісництва.

Досліджено вирубки за 2007-2017 рр. здорового лісу та сухостою. Для цього оцифровано ділянки вирубок здорового лісу на синтезованому знімку (рис. 10). Результати показали, що вирубано 55,5 га функціонального лісу. Також вирубки відбувалися на ділянках, де зауважено сухостій (67,8 га). 
Проведено моніторинг зміни стану лісових масивів за короткий період - 2017-2018 рр. Встановлено, що вирубки проводилися для очищення території та зменшення кількості сухостійних дерев (рис. 11). Площа санітарних вирубок становить 35,3 га. Прокладено лісову дорогу, якою можна дістатися до ділянок із засиханням хвойних дерев (рис. 13).

Оцінку точності класифікації обчислюємо за формулами (2), (3) [Волосецький, 2012]:

$$
\begin{gathered}
m_{s}=m_{t} \sqrt{S} \sqrt{\frac{1+k^{2}}{2 k}}, \\
m_{t}=m_{x} \sqrt{2},
\end{gathered}
$$

де $m_{t}-$ СКП визначення відстаней; $k$ - кількість поворотних точок; $m_{x}-$ розрізнення знімка.

СКП визначення площі для Landsat $5\left(m_{x}=30\right.$ м) становить $16 \%$, для Sentinel $2\left(m_{x}=10\right.$ м $)-5,4 \%$.

\section{Висновки}

Для моніторингу стану лісів Тухлянського лісництва використано комплексну методику, яка грунтується на проведенні польових досліджень та виконанні контрольованої класифікації за космічними знімками із супутників Landsat 5 (2007 р.) та Sentinel 2 (2017 і 2018 роки).

3 метою обстеження стану лісів та збирання завіркової інформації для створення навчальних вибірок проведено дві польові експедиції.

Для реалізації контрольованої класифікації методом максимальної вірогідності встановлено такі класи: лісові масиви, ділянки із засиханням хвойних дерев, галявини та стежки. Застосовано постоброблення та визначено площі цих класів. Порівняння площ вказує на різницю між даними досліджень у відповідні роки. Встановлено, що площа засихання дерев за десять років (20072017 рр.) збільшилось на 223,5 га, а через інтенсивне вирубування засохлих дерев у 20172018 pр. їх площа зменшилася на 20,3 га. Також визначено нові ділянки із засиханням хвойних дерев.

\section{Лiтература}

Bochenek, Z., Ziolkowski, D., Bartold, M., Orlowska K. and Ochtyra, A. (2017). Monitoring forest biodiversity and the impact of climate on forest environment using high-resolution satellite images. European Journal of Remote Sensing, Vol. 51, 166-181.

Burshtynska, K., Polishchuk, B., Madyar, J. (2014). The definition of the area of felling forests by high resolution satellite images. GLL, No. 3, 43-54.

Grinandabc, G., Rakotomalalacd, F., Gonde, V., Vaudryc, R., Bernouxg, M. and Vieilledentef G.
(2013). Estimating deforestation in tropical humid and dry forests in Madagascar from 2000 to 2010 using multi-date Landsat satellite images and the random forests classifier. Remote Sensing of Environment, Vol. 139, 68-80.

Hais, M., Wild, J., Berec, L., Brůna, J., Kennedy, R., Braaten, J., Brož, Z. (2016). Landsat Imagery Spectral Trajectories-Important Variables for Spatially Predicting the Risks of Bark Beetle Disturbance. Remote Sensing, Vol. 8, 687.

Viewegh, J., Kusbach, A., Mikeska, M. (2003). Czech forest ecosystem classification. Journal of forest science, Vol. 49, 74-82.

Бурштинська Х., Поліщук Б., Ковальчук О. (2013). Дослідження методів класифікації лісів 3 використанням космічних знімків високого розрізнення. Геодезія, картографія та аерофотознімання, Вип. 78, 101-110.

Волосецький Б. (2012). Геодезія у природокористуванні: навч. посіб. Л.: Вид-во Львів. політехніки.

Денис Ю., Паштетник О., Поліщук Б. (2017). Дослідження стану хвойних лісів Прикарпатського регіону з використанням космічних знімків. Міжнародна науково-технічна конференція молодих вчених "GeоTerrace-2017" 14-16 грудня 2017 р., Львів, Україна: Видавництво Львівської політехніки.

Зацерковний В., Тішаєв О., Шишенко О. (2016). Застосування матеріалів дистанційного зондування в завданнях моніторингу лісових пожеж i кількісного оцінювання рослинності. Наукоємні технологї, Вип. № 1 (29), 42-47.

Зацерковний В., Оберемок Н., Ягорлицька К. (2017). Застосування технологій ГІС і ДЗ3 в задачах моніторингу лісових ценозів. Наукоємні технологіï, Вип. № 4 (36), 350-357.

Котляревська Н. (2010). Лісове господарство України: розвиток і проблеми сьогодення. Актуальні проблеми економіки, Вип. 107 (№ 5). 30-36.

Лялько В., Попов М. (2006). Багатоспектральні методи дистанційного зондування Землі в задачах природокористування. К.: Наукова думка

Миклуш С., Гаврилюк С., Часковський О. (2012). Дистанційне зондування Землі в лісовому господарстві. Львів: ЗУКЦ.

Шпак А. (2012). Порівняльний аналіз методів класифікації лісів гірської місцевості за матеріалами знімання супутника RapidEye. Вісник Астрономічної школи, Т. 8, № 2, 212-216.

ДП “Славське лісове господарство” [Електронний pecypc]. Режим доступу: http://slavsklis.com.ua 


\section{KH. BURSHTYNSKA, YU. DENYS, O. PASHTETNYK}

Department of photogrammetry and geoinformatic, Lviv Polytechnic National University, 12, S. Bandery str., Lviv, Ukraine, 79013, e-mail: yuliya.denys@ gmail.com

\section{MONITORING OF CONIFEROUS FORESTS DRYING BY DIFFERENT TIME SATELLITE IMAGES (FOR TUKHLYA FORESTRY)}

The purpose of the work is to identify areas with coniferous forest drying on the basis of spectral brightness of images using field research and to create training samples for controlled classification in order to calculate the areas with the drying of coniferous forest. Methodology. To monitor the condition of forests in Tukhlya forestry, a complex methodology, based on the use of time-varying medium-resolution satellite images with further postprocessing by geoinformation systems, is used. In the research area in 2007, based on materials of aerosurveying using an electro-optical camera, orthophotomaps with marked areas drying of coniferous trees were created,. Field researchs consisted of identifying the five selected on orthophotomaps areas and identifying changes regarding the drying of coniferous forests over a decade. The research concerned the selection of test samples for the further processing of satellite images received from satellites Landsat 5 (2007) and Sentinel 2 (2017 and 2018) by controlled classification method. The controlled classifications allows to determine the extent of drying forests over the past 11 years, changing the landscape and determining the area of drying forests. Results. The research was conducted on the territory of Tukhlya Forestry, Skolivsky District, Lviv Oblast. For field researchs, five areas with known coordinates have been selected, in which forest drying was detected. Two expeditions were organized for the purpose of collecting information on these areas. By using verification data, training samples have been created. Histograms and scatter diagrams are used to evaluate the training samples. The controlled classification by the maximum probability method was performed on the territory of forestry with further postprocessing. New areas with coniferous forest drying have been identified and the area of drying has been determined. Scientific novelty and practical significance. The proposed methodology allows to monitor forest areas with sufficient accuracy, and to control the spread of drying in forests, and, accordingly, to take timely management decisions to reduce the distribution of pests in coniferous forests. This methodology and the obtained research results should be used in forestry for operational forest monitoring.

Keywords: monitoring of forest; coniferous forest drying; satellite images; classification; training samples.

\section{References}

Bochenek, Z., Ziolkowski, D., Bartold, M., Orlowska K. and Ochtyra, A. (2017). Monitoring forest biodiversity and the impact of climate on forest environment using high-resolution satellite images. European Journal of Remote Sensing, Vol. 51, $166-181$.

Burshtynska, K., Polishchuk, B., Madyar, J. (2014). The definition of the area of felling forests by high resolution satellite images. GLL, No. 3, 43-54.

Grinandabc, G., Rakotomalalacd, F., Gonde, V., Vaudryc, R., Bernouxg, M. and Vieilledentef G. (2013). Estimating deforestation in tropical humid and dry forests in Madagascar from 2000 to 2010 using multi-date Landsat satellite images and the random forests classifier. Remote Sensing of Environment, Vol. 139, 68-80.

Hais, M., Wild, J., Berec, L., Brůna, J., Kennedy, R., Braaten, J., Brož, Z. (2016). Landsat Imagery Spectral TrajectoriesImportant Variables for Spatially Predicting the Risks of Bark Beetle Disturbance. Remote Sensing, Vol. 8, 687.

Viewegh J., Kusbach A., Mikeska M. (2003). Czech forest ecosystem classification. Journal of forest science, Vol. 49, 74-82.

Burshtynska, Kh., Polishchuk, B., Kovalchuk, O. (2013). Doslidzhennia metodiv klasyfikatsii lisiv z vykorystanniam kosmichnykh znimkiv vysokoho rozriznennia. Heodeziia, kartohrafiia ta aerofotoznimannia, Vyp. 78, 101-110.

Volosetskyi B. (2012). Heodeziia u pryrodokorystuvanni: navch. posib. L.: Vyd-vo Lviv. Politekhniky.

Denys, Yu., Pashtetnyk, O., Polishchuk, B. (2017) Doslidzhennia stanu khvoinykh lisiv Prykarpatskoho rehionu z vykorystanniam kosmichnykh znimkiv. Mizhnarodna naukovo-tekhnichna konferentsiia molodykh vchenykh "GeoTerrace-2017" 14-16 hrudnia 2017r., Lviv, Ukraina: Vydavnytstvo Lvivskoi politekhniky.

Zatserkovnyi V., Tishaiev O., Shyshenko O. (2016). Zastosuvannia materialiv dystantsiinoho zonduvannia v zavdanniakh monitorynhu lisovykh pozhezh i kilkisnoho otsiniuvannia roslynnosti. Naukoiemni tekhnolohii, Vyp. No. 1 (29), $42-47$.

Zatserkovnyi V., Oberemok N., Yahorlytska K. (2017). Zastosuvannia tekhnolohii HIS i DZZ v zadachakh monitorynhu lisovykh tsenoziv. Naukoiemni tekhnolohii, Vyp. No. 4 (36), 350-357.

Kotliarevska N. (2010). Lisove hospodarstvo Ukrainy: rozvytok i problemy sohodennia. Aktualni problemy ekonomiky, Vyp. 107 (No. 5). 30-36.

Lialko V., Popov M. (2006). Bahatospektralni metody dystantsiinoho zonduvannia Zemli v zadachakh pryrodokorystuvannia. K.: Naukova dumka.

Myklush S., Havryliuk S., Chaskovskyi O. (2012). Dystantsiine zonduvannia Zemli v lisovomu hospodarstvi. Lviv: ZUKTs.

Shpak A. (2012). Porivnialnyi analiz metodiv klasyfikatsii lisiv hirskoi mistsevosti za materialamy znimannia suputnyka RapidEye. Visnyk Astronomichnoi shkoly, T. 8, No. 2, 212-216.

DP "Slavske lisove hospodarstvo" [Elektronnyi resurs]. Rezhym dostupu: http://slavsklis.com.ua 